\title{
The Favoured Treatment: Social-Legal Aspect
}

\author{
Natalya A. Frolova ${ }^{a}$, Vladislav Yu. Panchenko ${ }^{\text {b* }}$ \\ and Ivan Yu. Makarchuk ${ }^{b}$ \\ ${ }^{a}$ The Russian Presidential Academy of \\ National Economy and Public Administration \\ 84/6 Vernadsky, Moscow, 119571, Russia \\ ${ }^{b}$ Siberian Federal University \\ 79 Svobodny, Krasnoyarsk, 660041, Russia
}

Received 26.03.2016, received in revised form 15.04.2016, accepted 25.06.2016

The article discusses the establishment of the most favoured nation treatment in respect of some members of the Russian legal life. The authors conclude that the legal treatment is a kind of the incentive treatment; it is consolidated in various sectors of the Russian law (for example, defense favoured treatment and a special legal treatment for the restoration of rights violated as a result of illegal and unjustified criminal prosecution are introduced by the rules of criminal procedure, tax law knows the institutions of offshore and special economic zones, etc.); it can be understood as 'creating the best and the most favoured conditions for someone'. The importance of a direct reference to establishing the favoured treatment and expanding the scope of its application in the regulations is caused by the urgent needs for streamlining the relevant areas of legal regulation, improving the effectiveness of legal norms, providing the the most complete realization of rights and legitimate interests, as well as the early achievement of the purposes, which the Russian national legal system faces.

Keywords: the most favoured nation treatment, legal incentive, realization of rights and legitimate interests, legal policy, legal life.

This article was prepared with the support of the Russian Foundation for the Humanities. Project No. 15-33-01354.

DOI: 10.17516/1997-1370-2016-9-8-1841-1848.

Research area: philosophy.

The legal favoured treatment received a preferential distribution in the field of international trade. It means that each contracting state undertakes to grant another state, its citizens and legal entities rights, privileges and benefits in a particular area of their relationship as favoured as it grants or provide any third state, its citizens and legal entities in future. The most favoured nation treatment in international trade agreements does not equalize the rights of foreign citizens with the rights of local citizens, but equalizes the rights of foreign citizens among themselves. The

(C) Siberian Federal University. All rights reserved

* Corresponding author E-mail address: panchenkovlad@mail.ru 
scope of the most favoured nation treatment can cover the entire area of trade and navigation in a general way, or basing on an elective principle, can contain separate spheres of relations included in this sphere ${ }^{1}$, namely, the regulation of trade and payments (including customs duties, transit, quantitativeand otherrestrictionsand prohibitions, etc.); treatment of foreign means of transport, including sea and river vessels, aircrafts, railway rolling stock, vehicles, etc.; rights of foreign natural and legal entities (including internal taxes and charges). Less commonly, the principle of the most favoured nation treatment shall also be applied to diplomatic and consular immunities and privileges; exclusive rights (patents, copyright, etc.); recognition and enforcement of foreign judgments and arbitral awards ${ }^{2}$. The most favoured nation treatment helps to strengthen the equal cooperation between states. The refusal from the most favoured nation treatment is considered as international economic sanctions.

At the normative level the most favoured nation treatment contents are disclosed in Art. I of the General Agreement on Tariffs and Trade (hereinafter referred to as GATT ${ }^{3}$ ), 'With respect to customs duties and charges of any kind imposed on import and export, or in connection with them, or on the transfer of payments for imports or exports abroad, as well as with respect to the method of levying such duties and charges, and with respect to all regulatory rules and formalities in connection with importation or exportation $<_{\text {... }}>$ any advantage, favour, privilege or immunity granted by any contracting party in relation to any product originating in any other country or intended for any other country shall be accorded immediately and unconditionally to the similar product originating in the territories of all other contracting parties or intended for the territories of all other contracting parties'. It is noteworthy that in the first decade of functioning of the GATT most disputes arose in connection with the violation of the most favoured nation treatment. Currently, the number of such disputes has decreased markedly. This is due to the fact that the states provide each other with the targeted benefits, as a rule, within the framework of regional integration associations (free trade zones, customs, economic, currency unions, etc.) that are actually withdrawn out of control of the World Trade Organization (hereinafter referred to as $\mathrm{WTO})^{4}$.

Traditionally, the national legal treatment is mentioned along with the most favoured nation treatment. The principle of national treatment relates to one of the basic principles of international private law. The national treatment means equating foreign nationals, stateless persons and foreign legal entities in regard to their rights and obligations, to domestic individuals and legal entities. Since foreign individuals and entities subject to the same rights and benefits, which local individuals and legal entities use in this country, all of them are equalized ${ }^{5}$. That principle of providing the national treatment and the principle of the most favoured nation treatment are the key pillars of the GATT and the WTO system. They represent 'the unity, which organizes the legal space for international trade'6.

The analysis of the various sections of the Russian legal system can detect the establishment of the most favoured nation treatment with respect to some participants of legal life. Thus, in the Agreement on government (municipal) procurement, which was signed between the Government of the Republic of Belarus, the Government of the Republic of Kazakhstan and the Government of the Russian Federation in 2010 , the treatment is defined as providing goods (works, services), originating in the territories of states-parties, as well as suppliers and potential suppliers of states-parties offering such goods, performing works and rendering services, with 
the treatment that is no less favoured than that accorded to goods (works, services), originating in the territories of third countries, as well as suppliers and potential suppliers of third countries offering such goods, performing works and rendering services.

The treatment is also an effective means of combating corruption in the professional work of civil servants, when civil servants are obliged to act impartially, avoiding the most favoured nation treatment with respect to everyone, to make decisions with the maximum transparency, refraining from making or using privileged situations. It should be noted that in different kinds of corrupt activities the thing that is dangerous is its self-reproduction that is the establishment of stable illicit relationships, which involve a targeted involvement of fresh forces in criminal activities of individuals from both sides to create particularly the most favoured nation treatment.

In the Russian procedural science and practice the most favoured nation treatment is expressed in the defense favoured treatment (favor defensionis). The literature suggests that the subjects and participants in the legal process shall not be placed in special conditions, favoured or not to exercise their rights and legitimate interests, otherwise, the creation of favoured conditions for some and bad for others may lead to a breach of the adversarial principle ${ }^{7}$. It seems that a meaningful approach is necessary here. The adversarial legal procedure presupposes the equality of the parties and equidistance of an impartial and independent court from them, however, the prosecution presented (except for private prosecution cases) by state bodies is vested with governmental authority, including those necessary for conducting investigations and obtaining evidence, and of course, it possesses capabilities of defending its position that are not equal with the defense. In order to equalize the rights of the parties in adversarial proceedings, the Criminal Procedure Code of the Russian Federation provides a number of procedural benefits for the protection referred to as the defense favoured treatment. With regard to the process of proof, the specificity of the tasks standing in front of the defense is the basis of the defense favoured treatment. Laying the burden of proof, i.e., the obligation to establish the circumstances included in the item of proof, as well as the refutation of argumentation presented in the defense of the suspect or the accused, on the prosecution means that goal standing in front of it is the establishment of an event of a crime and a person who committed it. In view of the presumption of innocence, the suspect or the accused, and therefore also the defense as a whole are not required to prove their innocence, and all doubts about the guilt of the accused, which cannot be resolved in accordance with the law, shall be interpreted in favor of the accused. Therefore, the purpose of proof will be achieved for the defense, if there is doubt about the validity of the approval of the prosecution ${ }^{8}$. This treatment is of an undoubted importance in terms of providing the procedural equality of the parties. A similar treatment is detected in administrative proceedings, where, in spite of the legal equality of the parties before the law and the procedural equality, an individual actually is the weaker party in the process. The defense favoured treatment is one of the characteristic features of the legal treatment of administrative proceedings. It is intended to prevent the trial from turning into 'beating' of a formally equal, but actually weaker one. This principle determines the distribution of the burden of proof that is different from the one in civil proceedings, and causes the appearance of the principle of procedural activity of the court and others 9 .

Currently, other industry-favoured-nation treatments are being developed as well. The analysis of criminal-procedural standards 
and the existing court practice allows us to conclude that the Russian legal system has a special, privileged legal treatment to restore the rights violated as a result of the illegal and unjustified criminal prosecution, the application of coercive procedural measures that is the rehabilitation favoured treatment. The elements of the rehabilitation favoured treatment are: the law does not limit the circle of persons entitled to seek redress by the way of rehabilitation only to criminal trial participants; illegally or unreasonably limited rights are to be restored regardless of the final decision in the criminal case; a combination of public and non-mandatory mechanisms of a redress procedure; damage shall be compensated regardless of the fault of the state bodies and officials; damage shall be compensated by the state; the state's reimbursement of costs for legal aid provided in order to restore the victim's rights; alternative jurisdiction of the issue of compensation of property damage to the rehabilitated ${ }^{10}$.

The favoured nation treatment is of particular importance for offshore (Tax Code of the Russian Federation (Article 284) defines tax havens as states and territories with preferential tax treatment of taxation and (or) not involving the disclosure and provision of information on financial transactions) and special economic zones (a special economic zone is a part of the territory of the Russian Federation, which is determined by the Government of the Russian Federation and on which a special treatment of entrepreneurial activities acts, and where the customs procedure of free customs zone (Article 2 of the Federal law of July 22, 2005, No. 116-FZ 'On special economic zones in the Russian federation') can be applied). The most favoured nation treatment provides various benefits, which are aimed at the development of the investment policy of the Russian state with the help of attracting domestic and foreign funds through the creation of offshore and special economic zones ${ }^{11}$. The government is intended to support the favoured nation treatment in the economic sphere daily for participants of entrepreneurial activity in the sphere of the free market, the inviolability of property, the freedom of contract, the state of free competition, to prevent the abuse of economic freedom, to eliminate the adverse effects of such violations ${ }^{12}$.

The most favoured nation treatment consists of a whole system of attractive permissions, benefits and rewards with the creation of a favoured legal, providing certain advantages and benefits climate for subjects ${ }^{13}$. At the same time, in view of nonoccurence of the category of the most favoured nation treatment in the legislation, as well as legal and technical features of the legislative activity in Russia, the treatment is not always directly referred to in the regulations as the most favoured nation treatment, but essentially permissions, benefits and rewards, provided to the participants of the legal life, form it. In this case, it is necessary to resort to the interpretation of legal norms to qualify the given treatment as a favoured one. For example, in accordance with Paragraph 3 of Article 39 of the Constitution of the Russian Federation, 'Voluntary social insurance, creation of additional forms of social security and charity are stimulated'. Through interpretation, we conclude that the 'indication in the article to the stimulation of voluntary social insurance, creation of additional forms of social security and charity allow considering the creation of the legal favoured treatment for the formation and development of non-state forms of social security, adoption of organizational, legal and financial measures aimed at encouraging the participation of citizens, legal persons in their creation and activity as a duty of the state ${ }^{14}$.

We believe that a direct reference to the establishment of the favoured treatment in the regulations organizes the appropriate field of legal regulation, increases the effectiveness of 
legal rules, disciplines enforcers, and contributes to the fullest satisfaction of rights and legitimate interests, the early achievement of purposes.

The interpretation of the favoured nation treatment differs in the international and Russian law and doctrine. In one of the classic books on the international law we can find the following, 'in the normal (non-legal) language those, using the term the most favoured nation treatment, have in mind the creation of the most favoured conditions for someone. In reality it is not so, the most favoured national treatment differs from the national treatment by the fact that due to the most favoured national treatment foreign organizations and foreign citizens are equalized among themselves, and due to the national treatment they are equalized with domestic persons $<\ldots>$ Unlike the national treatment, the most favoured nation principle can be provided only by an international agreement ${ }^{15}$. In our opinion, the understanding of the most favoured nation treatment as 'creating the most favoured conditions for someone' is acceptable for the purposes of the Russian national legal system. The international law is a special system of legal norms, not including the rules of national legal systems ${ }^{16}$, so the negative effect of this approach is impossible.
Based on the foregoing, the legal favoured nation treatment should be understood as the procedure of legal regulation of social relations, expressed in a certain combination of permissions, benefits and rewards, to create favoured conditions for individuals and (or) legal entities in order to satisfy their interests and achieve socio-economic goals.

Obviously, the favoured nation treatment is a kind of the incentive treatment. The legal treatment of incentives is capable of motivating a person to active legitimate behavior, provides freedom of choice in making legally significant decisions. Using legal means, legal incentives encourage legal entities for law-abiding behavior, creating the favoured national treatment to meet the subject's own interests ${ }^{17}$. It is necessary to expand the scope of the application of the favoured nation treatment. A special attention should be paid to the favoured nation treatment in the field of human rights as 'human rights as a key link in the legal treatment of incentives for an individual is the source of constant reproduction of his initiative, enterprise, a tool of self-development of the civil society $<\ldots>$ They are becoming a much stronger reference point in national legal systems and legal regulation'18.

\footnotetext{
Horn, H., Marvoidis, P. C. (2001). Economic and legal aspects of the Most-Favored-Nation clause, In European Journal of Political Economy, 17, 233-279; Radi, Y. (2007). The Application of the Most-Favored-Nation Clause to the Dispute Settlement Provisions of Bilateral Investment Treaties: Domesticating the 'Trojan Horse', In European journal of International Law, 18 (4), 757-774; Hur, J., Park, D. (2004). Welfare Implications of RTAs within the WTO system in the presence of FDI, In Open Economies Review, 15 (1), 87-103; Ludema, R. D., Mayda A.M. (2013). Do Terms-of-Trade Effects Matter for Trade Agreements? Theory and Evidence from WTO Countries, In The Quarterly Journal of Economics, DOI: 10.1093/ qje/qjt016; Howse, R., Chalamish E. (2009). The Use and Abuse of WTO Law in Investor-State Arbitration: A Reply to Jürgen Kurtz, In European journal of International Law, 20 (4), 1087-1094, DOI: 10.1093/eji1/chp105.

2 Vel'iaminov, G.M. (2015). Mezhdunarodnoe parvo: opyty [International Law: experiences]. Moscow, Statut. Access from the reference legal system Consultant Plus.

3 General Agreement on Tariffs and Trade - a multilateral agreement, adopted in 1948 by many countries in the world, containing the rules for the conclusion of inter-state trade contracts and conducting international trade. Participants in the agreement grant each other favorable conditions for mutual trade. The agreement is intended to eliminate unnecessary restrictions and discrimination in the international trade. In 1995, the World Trade Organisation replaced the GATT.

4 Smbatian, A. (2014). Natsional'nyi rezhim regulirovaniia torgovli v traktovke organa po razresheniiu sporov VTO [National trade treatment represented by WTO Dispute Settlement Body], In Mezhdunarodnoe pravosudie [International Justice], 3, 114-115.

5 Boguslavskii, M.M. (2005). Mezhdunarodnoe chastnoe parvo: uchebnik [International Private Law. Textbook]. Moscow, Iurist". Access from the reference legal system Consultant Plus.

6 Fokov, A.P. (2015). Mezhdunarodnyi arbitrazhnyi sud ICC: mezhdunarodnye kontrakty v usloviiakh sanktsii [ICC Inter-
} 
national Court of Arbitration: international contracts under sanctions], In Mezhdunarodnoe publichnoe i chastnoe pravo [The international public and private law], 4, 24-27.

7 Beliaeva, G.S. (2013). K voprosu o sushchnosti protsessual'nogo pravovogo rezhima [On the issue about the nature of the procedural legal treatment], In Istoriia gosudarstva i prava [History of State and Law], 13, 63-64.

8 As detailed in Mikhailovskaia, I.B. (2007). Pravilo "blagopriiatstvovaniia" zashchite i ego vliianie na protsess dokazyvaniia [Protection favored standard and its impact on the process of proof], In Gosudarstvo i parvo [State and Law], 9, 41-49.

9 Zelentsov, A.B. (2015). Administrativnoe sudebnoe pravo: kontseptual'nye problemy formirovaniia [Administrative judicial law: conceptual problems of formation], In Administrativnoe parvo i protsess [Administrative law and process], 2, 39-46.

10 See for more details in Dikarev, I. (2012). Rezhim blagopriiatstvovaniia reabilitatsii v ugolovnom protsesse [Rehabilitation favored nation treatment in the criminal process], In Ugolovnoe pravo [Criminal Law], 4, 85-89.

11 Limanskaia, A.P. (2014). Spetsial'nye pravovye rezhimi: obshcheteoreticheskii analiz: diss. ... kand. iurid. nauk [Special legal treatments: general theoretical analysis. Ph.D. thesis in Law]. Rostov-on-Don, 34-35.

12 Alekseev, S.S. (1999). Filisofiia prava [Philosophy of Law]. Moscow, Norma, 319-320.

13 Mal'ko, A.V. (2004). Stimuli i ogranicheniia v prave [Incentives and restrictions in Law]. Moscow, Iurist", 209-210; Mal'ko, A.V., Kosak, A.V. (2012). Osnovy teorii pravovykh rezhimov [Foundations of the theory of legal treatments], In Pravovye rezhimy: obshcheteoreticheskie i otraslevye aspekty: monografiia / pod red. A.B. Mal'ko, I.S. Barzilova [Legal treatments: general theoretical and sectoral aspects. Monograph ed. by A.V. Mal'ko, I.S. Barzilova]. Moscow: Iurlitinform, 5-19; Morozova, I. (2004). Pravovye l'goty: ucheb. posobie / pod red. A.V. Mal'ko [Legal benefits: textbook ed. by A.V. Malko]. Saratov, CGAP, 6.

14 Andrichenko, L.V., Bogoliubov, S.A., Bondar', N.S. et al. (2011). Kommentarii k Konstitutsii Rossiiskoi Federatsii (postateinyi) pod red. V.D. Zor'kina [Commentary on the Constitution of the Russian Federation (itemized) ed. by V.D. Zor'kin]. Moscow, Norma, Infra-M. Access from the reference legal system Consultant Plus.

15 Boguslavskii, M.M. (2005). Mezhdunarodnoe chastnoe parvo: uchebnik [International Private Law. Textbook]. Moscow, Iurist". Access from the reference legal system Consultant Plus.

16 Boguslavskii, M.M. (2012). Kul'turnye tsennosti v mezhdunarodnom oborote: pravovye aspekty: monografiia [Cultural values in international turnover: Legal Aspects. Monograph]. Moscow, Norma, Infra-M. Access from the reference legal system Consultant Plus.

17 Mal'ko, A.V., Vyrleeva-Balaeva, O.S. (2012). Pravovoi rezhim ogranicheniia gosudarstvennoi vlasti [Legal treatment of limitation of state power], In Pravovye rezhimy: obshcheteoreticheskie i otraslevye aspekty: monografia / pod red. A.B. Mal'ko, I.S. Barzilova [Legal treatments: general theoretical and sectoral aspects. Monograph ed. by A.V. Mal'ko, I.S. Barzilova]. Moscow: Iurlitinform, 35.

18 Mal'ko, A.V. (1997). Pravovoe gosudarstvo [State of Law], In Pravovedenie [Jurisprudence], 3, 141.

\section{References}

Alekseev, S.S. (1999). Filisofiia prava [Philosophy of Law]. Moscow, Norma, 330 p.

Andrichenko, L.V., Bogoliubov, S.A., Bondar', N.S. et al. (2011). Kommentarii k Konstitutsii Rossiiskoi Federatsii (postateinyi) pod red. V.D. Zor'kina [Commentary on the Constitution of the Russian Federation (itemized) ed. by V.D. Zor'kin]. Moscow, Norma, Infra-M. Access from the reference legal system Consultant Plus.

Beliaeva, G.S. (2013). K voprosu o sushchnosti protsessual'nogo pravovogo rezhima [On the issue about the nature of the procedural legal treatment], In Istoriia gosudarstva i prava [History of State and Law], 13, 62-64.

Boguslavskii, M.M. (2012). Kul'turnye tsennosti v mezhdunarodnom oborote: pravovye aspekty: monografiia [Cultural values in international turnover: Legal Aspects. Monograph]. Moscow, Norma, Infra-M. Access from the reference legal system Consultant Plus.

Boguslavskii, M.M. (2005). Mezhdunarodnoe chastnoe pravo: uchebnik [International Private Law. Textbook]. Moscow, Iurist". Access from the reference legal system Consultant Plus.

Dikarev, I. (2012). Rezhim blagopriiatstvovaniia reabilitatsii v ugolovnom protsesse [Rehabilitation favoured treatment in the criminal process], In Ugolovnoe pravo [Criminal Law], 4, 85-89.

Fokov, A.P. (2015). Mezhdunarodnyi arbitrazhnyi sud ICC: mezhdunarodnye kontrakty v usloviiakh sanktsii [ICC International Court of Arbitration: international contracts under sanctions], In Mezhdunarodnoe publichnoe $i$ chastnoe pravo [The international public and private law], 4, 24-27. 
Horn, H., Marvoidis, P. C. (2001). Economic and legal aspects of the most-Favoured-Nation clause, In European Journal of Political Economy, 17, 233-279.

Howse, R., Chalamish E. (2009). The Use and Abuse of WTO Law in Investor-State Arbitration: A Reply to Jürgen Kurtz, In European journal of International Law, 20 (4), 1087-1094, DOI: 10.1093 / ejil / chp105.

Hur, J., Park, D. (2004). Welfare Implications of RTAs within the WTO system in the presence of FDI, In Open Economies Review, 15 (1), 87-103.

Ludema, R. D., Mayda, A.M. (2013). Do Terms-of-Trade Effects Matter for Trade Agreements? Theory and Evidence from WTO Countries, In The Quarterly Journal of Economics, DOI: 10.1093 / qje / qjt016.

Limanskaia, A.P. (2014). Spetsial'nye pravovye rezhimi: obshcheteoreticheskii analiz: diss. ... kand. iurid. nauk [Special legal treatments: general theoretical analysis. Ph.D. thesis in Law]. Rostovon-Don, $186 \mathrm{p}$.

Mal'ko, A.V. (1997). Pravovoe gosudarstvo [State of Law], In Pravovedenie [Jurisprudence], 3, 137-146.

Mal'ko, A.V. (2004). Stimuli i ogranicheniia v prave [Incentives and restrictions in Law]. Moscow, Iurist", $250 \mathrm{p}$.

Mal'ko, A.V., Vyrleeva-Balaeva, O.S. (2012). Pravovoi rezhim ogranicheniia gosudarstvennoi vlasti [Legal treatment of limitation of state power], In Pravovye rezhimy: obshcheteoreticheskie $i$ otraslevye aspekty: monografiia / pod red. A.B. Mal'ko, I.S. Barzilova [Legal treatments: general theoretical and sectoral aspects. Monograph ed. by A.V. Mal'ko, I.S. Barzilova]. Moscow: Iurlitinform, 499.

Mal'ko, A.V., Kosak, A.V. (2012). Osnovy teorii pravovykh rezhimov [Foundations of the theory of legal treatments], In Pravovye rezhimy: obshcheteoreticheskie i otraslevye aspekty: monografiia I pod red. A.B. Mal'ko, I.S. Barzilova [Legal treatments: general theoretical and sectoral aspects. Monograph ed. by A.V. Mal'ko, I.S. Barzilova]. Moscow: Iurlitinform, 499.

Mikhailovskaia, I.B. (2007). Pravilo "blagopriiatstvovaniia" zashchite i ego vliianie na protsess dokazyvaniia [The defense favoured standard and its impact on the process of proof], In Gosudarstvo i parvo [State and Law], 9, 41-49.

Morozova, I. (2004). Pravovye l'goty: ucheb. posobie / pod red. A.V. Mal'ko [Legal benefits: Textbook ed. by A.V. Malko]. Saratov, CGAP, 68 p.

Radi, Y. (2007). The Application of the Most-Favoured-Nation Clause to the Dispute Settlement Provisions of Bilateral Investment Treaties: Domesticating the 'Trojan Horse', In European journal of International Law, 18 (4), 757-774.

Vel'iaminov, G.M. (2015). Mezhdunarodnoe parvo: opyty [International Law: experiences]. Moscow, Statut. Access from the reference legal system Consultant Plus.

Zelentsov, A.B. (2015). Administrativnoe sudebnoe pravo: kontseptual'nye problemy formirovaniia [Administrative judicial law: conceptual problems of formation], In Administrativnoe parvo i protsess [Administrative law and process], 2, 39-46.

Smbatian, A. (2014). Natsional'nyi rezhim regulirovaniia torgovli $\mathrm{v}$ traktovke organa po razresheniiu sporov VTO [National trade treatment represented by WTO Dispute Settlement Body], In Mezhdunarodnoe pravosudie [International Justice], 3, 114-123. 


\title{
Режим благоприятствования:
}

социально-правовой аспект

\author{
Н.А. Фролова ${ }^{\text {, }}$ В.Ю. Панченко \\ И.Ю. Макарчук ${ }^{\sigma}$ \\ a Российская академия государственной службы \\ и народного хозяйства \\ при Президенте Российской Федерации \\ Россия, 119571, Москва, пр. Вернадского, 84 \\ ${ }^{6}$ Сибирский федеральный университет \\ Россия, 660041, Красноярск, пр. Свободный, 79
}

В статье рассматривается вопрос установления режима наибольшего благоприятствования 8 отнотении некоторых участников российской правовой жизни. Авторы приходят к выводам о том, что рассматриваемый правовой режим выступает разновидностью режима стимулирования; получает закрепление в различных отраслях российского права (например, уголовно-процессуальными нормами вводится режим благоприятствования защите и особый правовой режим восстановления прав, нарушенных в результате незаконного и необоснованного уголовного преследования, налоговому праву известны институты оффшорных и особых экономических зон и т. д.); может пониматься как «создание для когото самых лучших, благоприятных условий». Значимость прямого указания в нормативных актах на установление режима благоприятствования и расширения сферы его применения обусловлена актуальными потребностями в упорядочении соответствующих участков правового регулирования, повышении эффективности правовых норм, обеспечении наиболее полной реализации прав и законных интересов, а также в скорейшем достижении стоящих перед российской наииональной правовой системой целей.

Ключевые слова: режим наибольшего благоприятствования, правовое стимулирование, реализация прав и законных интересов, правовая политика, правовая жизнь.

Статья подготовлена при поддержке Российского гуманитарного научного фонда. Проект № 15-33-01354.

Научная специальность: 09.00.00 - философские науки. 